International Journal of Life Sciences
Available online at www.sciencescholar.us
Vol. 4 No. 2, August 2020, pages: $19-31$
e-ISSN: 2550-6986, p-ISSN: 2550-6994
https://doi.org/10.29332/ijls.v4n2.429

\title{
Impact of Tourism on Development in Bali Province
}

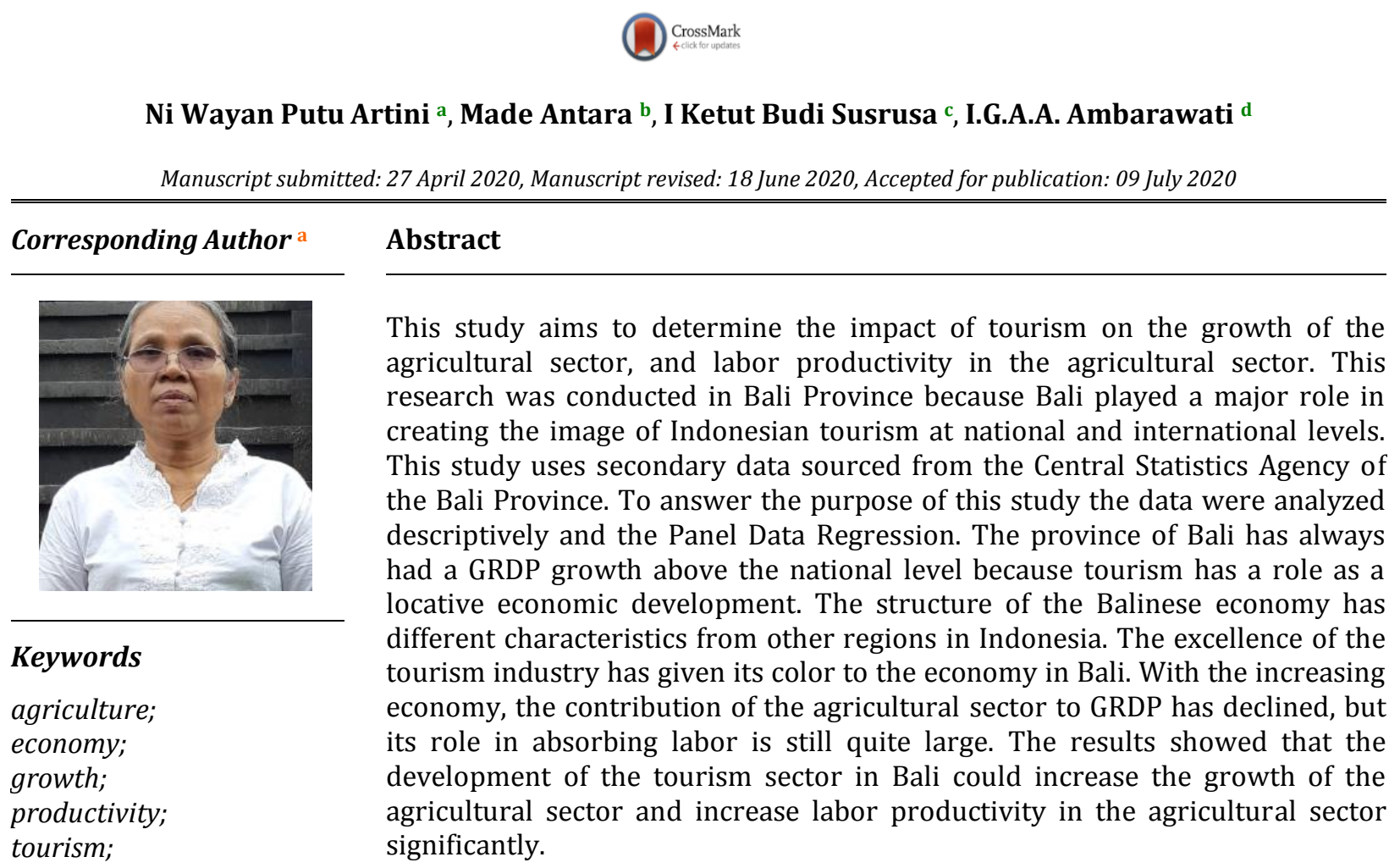

International Journal of Life Sciences (C) 2020.

This is an open access article under the CC BY-NC-ND license (https://creativecommons.org/licenses/by-nc-nd/4.0/).

\section{Contents}

Abstract

1 Introduction.

2 Materials and Methods

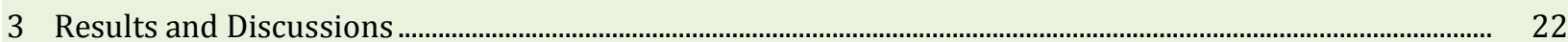

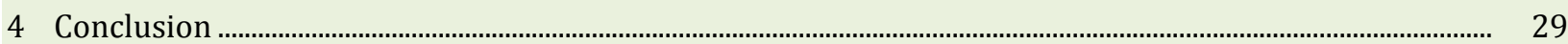

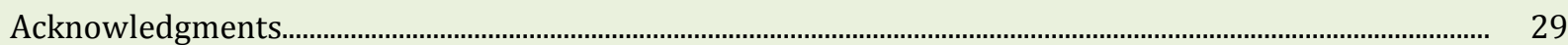

a Faculty of Agriculture, Universitas Udayana, Denpasar, Indonesia

b Faculty of Agriculture, Universitas Udayana, Denpasar, Indonesia

c Faculty of Agriculture, Universitas Udayana, Denpasar, Indonesia

d Faculty of Agriculture, Universitas Udayana, Denpasar, Indonesia 


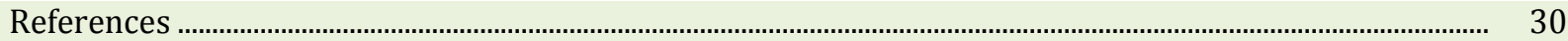

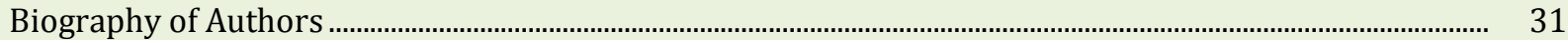

\section{Introduction}

Indonesia is an agrarian country, meaning that agriculture plays an important role in the national economy. This can be shown by the large population working in the agricultural sector. The importance of the agricultural sector, based on the fact that the agricultural sector is a sector that contributes greatly to GRDP, With the increasing development of the Indonesian economy, the contribution of the agricultural sector to GRDP from year to year tends to decrease.

The agricultural sector which has decreased its contribution to GRDP continues to accommodate a large workforce. In 2017 the agricultural sector which only contributed $14.35 \%$ to the GRDP absorbed 19.44\% of the population. The gap in farmers' welfare compared to workers in other sectors is still widening. Development economists recognize that the agricultural sector has a large role in the economy, especially in the early stages of development (Lewis, 1954; Johnston and Melor, 1961; Kuznets, 1964 in Harianto, 2007). While the current condition of farmers is very poor. Access to productive resources is very limited, land ownership is increasingly narrow, most farmers in Indonesia and also in Bali can be categorized as small farmers (Amerta et al., 2018; Belisle \& Hoy, 1980; Davenport \& Davenport, 2006). This means it is difficult to improve the welfare of farmers if it only relies on farming. Therefore there needs to be an opportunity to earn income from outside the farm.

Bali tourism has become a leading sector or engine that has been proven capable of sustaining the economy (Pitana, 1999; Seetanah, 2011; Wisudawati \& Maheswari, 2018). The results of the development of the Bali Region are quite amazing, the rate of economic growth in Bali is always above the average national economic growth. The high growth comes from various sectors and the most prominent is the tourism sector. Bali's economic structure has different characteristics compared to other regions in Indonesia. The excellence of the tourism industry has given its color to the economy in Bali (Fletcher, 1989; Milman \& Pizam, 1988; Perdue et al., 1987). This causes the sectors that have a relationship with tourism are very dominant in contributing to the economy. A shift in the role of the agricultural sector which was replaced by tourism as indicated by a shift in contributions to the GRDP shows the ongoing structural changes in the economy in Indonesia and Bali.

From the problems outlined above, the purpose of this study is to determine the impact of tourism development on the growth of the agricultural sector and labor productivity in the agricultural sector in the Province of Bali. This research is expected to be able to provide benefits to the government, as information material in determining agricultural and tourism development policies as the main step to improve people's welfare. For other researchers as initial information, material to conduct similar research with a broader and deeper scope.

\section{Materials and Methods}

This research was conducted in Bali Province. The choice of location is done with certain considerations:

1) In Bali Province tourism has become a leading sector in the economy that can sustain the economy

2) In the Province of Bali developed cultural tourism, namely Hindu culture which is rooted in the agricultural sector.

3) Bali Province is one of the prominent tourist areas in Indonesia and is already well-known in the world

4) The Province of Bali plays a major role in the creation of Indonesia's tourism image at the national and international levels.

In this study, the data used are secondary data sourced from the Central Statistics Agency of Bali Province. The data used in this study include Bali GRDP, Bali population, Bali agricultural production, and so on. This research uses secondary data. In this research, the method used to collect data is documentation, which is to collect data and information from institutions/institutions that are related to research. Data and information are taken from documents in the Central Statistics Agency, the results of previous studies, and other 
references used as a theoretical basis to support this research. In this study, quantitative data were analyzed by Panel Data Regression while qualitative data were analyzed by descriptive qualitative. Panel data is a combination of cross-section data and time-series data. In this study, the panel regression model used is a double-log regression model to obtain the elasticity of the independent variable on the dependent variable. Mathematically, the elasticity coefficient of the double-log model can be formulated as follows:

$$
\begin{gathered}
\ln y=\alpha+\beta \ln x \\
\beta=\frac{\ln y}{\ln x}=\frac{\int_{i=1}^{n} \frac{d y}{y}}{\int_{i=1}^{n} \frac{d x}{x}}=\frac{\sum_{i=1}^{n} \frac{\Delta y}{y}}{\sum_{i=1}^{n} \frac{\Delta x}{x}}
\end{gathered}
$$

The equation above shows that the coefficient $\beta$ can be used to see the elasticity of the variable $\mathrm{x}$ with $\mathrm{y}$. Furthermore, to determine the impact of tourism development on the growth of the agricultural sector, Panel Data Regression analysis is performed with the formula:

$$
\ln y_{i t}=\alpha+\beta \ln x_{i t}+e
$$

Information:

$y_{i t}:$ Growth in the agriculture sector in Bali Province

$\mathrm{x}_{\mathrm{it}}$ : Development of Tourism in the Province of Bali

e : Error

$\alpha$ : Interception

$\beta$ : Elasticity

Furthermore, to determine the impact of tourism development on labor productivity in the agricultural sector, Panel Data Regression analysis is performed with the formula:

$$
\ln P_{i t}=\alpha+\beta \ln x_{i t}+e
$$

Information:

$P_{i t}$ : Productivity of labor in the agricultural sector of the Province of Bali

$\mathrm{x}_{\mathrm{it}}$ : The development of tourism in the Province of Bali

e : Error

$\alpha$ : Interception

$\beta$ : Elasticity

Productivity, in this case, is calculated using the formula:

$$
\text { Produktivity }_{i}=\frac{\text { GRDP }_{i}}{\text { Number of } \text { Worker }_{i}}
$$

Information:

Productivity $y_{i}=$ Labor productivity in the agricultural sector

$\mathrm{GRDP}_{\mathrm{i}} \quad=$ GRDP agricultural sector prices are constant

Number of Worker $_{i}=$ Number of workers in the agricultural sector

Artini, N. W. P., Antara, M., Susrusa, I. K. B., \& Ambarawati, I. (2020). Impact of tourism on development in Bali Province. International Journal of Life Sciences, 4(2), 19-31. https://doi.org/10.29332/ijls.v4n2.429 


\section{Results and Discussions}

\subsection{General Overview of Bali Economy}

During the last five years (2013-2017), the structure of the Balinese economy has not changed much. The biggest contribution is contributed by the tourism industry. The second-largest contribution came from the agricultural business field. The tourism industry's contribution tends to increase, but conversely, the agricultural industry's business tends to decrease. In 2013 the contribution of the tourism industry (the provision of accommodation and food and drink) was recorded at $21.53 \%$ and increased to $23.33 \%$ in 2017 . In that period, the contribution increased by $1.8 \%$. The increase in the contribution of the tourism industry is in line with the increase in the number of foreign tourists visiting Bali. The number of tourist arrivals in 2013 was $3,278,598$ people, increasing to $5,697,739$ in 2017. In that period, the number of visits increased by $73 \%$ or $14.21 \%$ annually.

\subsection{Economic Structure}

The economic structure in an area/region can be seen from the composition of all production activities that occur in that region/region. If there is a shift in the composition of each industry, the structure of the economy will also change. One indicator that is often used to observe the economic structure of a region/region is the distribution of the gross value added to the business field. The economic structure of the Province of Bali is presented in Table 1.

Table 1

Economic Structure of Bali Province based on current prices according to the business field in 2013-2017 (\%)

\begin{tabular}{|c|c|c|c|c|c|}
\hline \multirow{2}{*}{$\begin{array}{l}\text { Business field } \\
\text { (category) }\end{array}$} & \multicolumn{5}{|c|}{ Year } \\
\hline & 2013 & 2014 & 2015 & 2016 & 2017 \\
\hline Agriculture, forestry and fisheries (A) & 15,22 & 14,65 & 14,65 & 14,67 & 14,35 \\
\hline Mining and quarrying (B) & 1,31 & 1,25 & 1,11 & 1,08 & 0,98 \\
\hline Processing industry (C) & 6,44 & 6,38 & 6,53 & 6,38 & 6,05 \\
\hline & 0,13 & 0,15 & 0,19 & 0,22 & 0,24 \\
\hline Electricity and gas supply (D) & 0,20 & 0,18 & 0,18 & 0,18 & 0,18 \\
\hline $\begin{array}{l}\text { Water supply, waste management, } \\
\text { waste and recycling (E) }\end{array}$ & 9,86 & 9,02 & 8,86 & 8,85 & 8,83 \\
\hline Construction (F) & 8,31 & 8,27 & 8.34 & 8,33 & 8,61 \\
\hline $\begin{array}{l}\text { Wholesale and retail trade, auto and } \\
\text { motorcycle repair (G) }\end{array}$ & 8,42 & 9,08 & 9,29 & 9,57 & 9,45 \\
\hline Transportation and warehousing $(\mathrm{H})$ & 21,53 & 23,10 & 23,01 & 22,76 & 23,33 \\
\hline $\begin{array}{l}\text { Provision of accommodation and food } \\
\text { and drink (I) }\end{array}$ & 5,44 & 5,14 & 5,17 & 5,16 & 5,13 \\
\hline Information and communication (J) & 4,30 & 4,19 & 4,12 & 4,14 & 3,98 \\
\hline Financial and insurance services (K) & 4,44 & 4,36 & 4,19 & 4,04 & 3,90 \\
\hline Real Estate (L) & 1,00 & 0,98 & 1,02 & 1,05 & 1,06 \\
\hline Company services $(\mathrm{M}, \mathrm{N})$ & 5,09 & 5,01 & 4,95 & 4,92 & 5,07 \\
\hline $\begin{array}{l}\text { Government administration, defense, } \\
\text { and mandatory social security }(0)\end{array}$ & 4,82 & 4,77 & 4,85 & 5,05 & 5,13 \\
\hline Educational services (P) & 1,99 & 1,98 & 2,05 & 2,10 & 2,15 \\
\hline $\begin{array}{l}\text { Health services and social activities } \\
\text { (Q) }\end{array}$ & 1,50 & 1,48 & 1,49 & 1,53 & 1,55 \\
\hline Total & 100,00 & 100,00 & 100,00 & 100,00 & 100,00 \\
\hline
\end{tabular}

From Table 1 it can be seen that with the development of tourism in Bali, the structure of the economy has changed. This is evident from the contribution of each sector in shaping the Bali GRDP. The sector of providing 
accommodation and food and drink which is the sector with the greatest connection to tourism gives the most dominant share for Bali's GRDP even shows an increasing trend from year to year. In contrast, the agriculture, forestry, and fisheries sectors, although still ranked second in the contribution to Bali's GRDP, have gradually declined in their role.

\subsection{Economic Growth}

This growth rate is very important to study because it is more often used in decision making and policy. An area or region is said to experience economic growth if there is an increase in real GRDP in the region or region. Economic growth, which is shown by GRDP growth at constant prices, indirectly illustrates the level of production changes that occur in an area or region.

Here is presented data on the growth of the Bali economy in 2013-2017. In 2017 the growth of the Balinese economy based on constant prices reached 5.59\% while the national growth reached $4.98 \%$. In 2017 the highest growth rate in the Balinese economy occurred in the dining and drinking accommodation busin ess by $9.25 \%$. Bali's economic growth based on constant prices is presented in Table 2 .

Table 2

Bali Province economic growth based on constant prices in 2013-2017

\begin{tabular}{|c|c|c|c|c|c|c|}
\hline Category & Description & 2013 & 2014 & 2015 & 2016 & 2017 \\
\hline A & $\begin{array}{l}\text { Agriculture, forestry and } \\
\text { fisheries }\end{array}$ & 2,20 & 4,66 & 2,68 & 3,55 & 2,88 \\
\hline B & Mining and excavation & 7,70 & $(0,60)$ & $(6,83)$ & 4,28 & $(1,44)$ \\
\hline $\mathrm{C}$ & Processing industry & 8,59 & 8,88 & 6,93 & 3,37 & 0,86 \\
\hline $\mathrm{D}$ & Electricity and gas supply & 7,64 & 8,97 & 1,59 & 8,31 & 5,48 \\
\hline E & $\begin{array}{l}\text { Water supply, waste } \\
\text { management, waste and } \\
\text { recycling }\end{array}$ & 5,39 & 7,40 & 1,99 & 6,34 & 2,72 \\
\hline $\mathrm{F}$ & Construction & 5,95 & 1,80 & 5,01 & 7,26 & 7,69 \\
\hline G & $\begin{array}{l}\text { Wholesale and retail trade, } \\
\text { car and motorcycle repair }\end{array}$ & 9,09 & 7,17 & 7,94 & 6,61 & 7,84 \\
\hline $\mathrm{H}$ & $\begin{array}{l}\text { Transportation and } \\
\text { warehousing }\end{array}$ & 6,72 & 5,84 & 4,63 & 8,17 & 4,99 \\
\hline I & $\begin{array}{l}\text { Provision of accommodation } \\
\text { and eating and drinking }\end{array}$ & 7,90 & 6,82 & 6,31 & 6,48 & 9,25 \\
\hline $\mathrm{J}$ & $\begin{array}{l}\text { Information and } \\
\text { communication }\end{array}$ & 5,78 & 7,21 & 9,67 & 8,74 & 8,14 \\
\hline $\mathrm{K}$ & $\begin{array}{l}\text { Financial and insurance } \\
\text { services }\end{array}$ & 12,73 & 8,34 & 6,66 & 8,06 & 2,43 \\
\hline $\mathrm{L}$ & Real state & 6,98 & 8,89 & 5,12 & 4,74 & 3,78 \\
\hline $\mathrm{M}, \mathrm{N}$ & Company services & 9,00 & 7,49 & 6,99 & 6,85 & 6,91 \\
\hline 0 & $\begin{array}{l}\text { Government administration, } \\
\text { defense and mandatory } \\
\text { social security }\end{array}$ & 0,02 & 10,75 & 8,27 & 5,44 & $(1,59)$ \\
\hline $\mathrm{P}$ & Educational services & 13,48 & 10,58 & 8,95 & 8,91 & 7,00 \\
\hline Q & $\begin{array}{l}\text { Health services and social } \\
\text { activities }\end{array}$ & 12,80 & 12,43 & 8,76 & 8,65 & 8,44 \\
\hline \multirow[t]{2}{*}{$\mathrm{R}, \mathrm{S}, \mathrm{T}, \mathrm{U}$} & Other services & 4,22 & 7,63 & 7,45 & 8,82 & 7,98 \\
\hline & Growth rate & 6,69 & 6,73 & 6,03 & 6,32 & 5,59 \\
\hline
\end{tabular}

Source: Central Statistics Agency (Bali in Number) 2014, 2015

Central Statistics Agency (Bali GRDP) 2013-2018

Artini, N. W. P., Antara, M., Susrusa, I. K. B., \& Ambarawati, I. (2020). Impact of tourism on development in Bali Province. International Journal of Life Sciences, 4(2), 19-31. https://doi.org/10.29332/ijls.v4n2.429 
Bali Province can no longer be denied that tourism is a leading sector in the economy. As a leading sector, tourism provided the largest contribution to GRDP (23.33\%) in 2017, while in the same year, agriculture was only able to contribute $14.35 \%$. Bali's economic growth is always above the average national economic growth because Bali is a tourism area and in Bali tourism as a generator of development. Economic activities that are directly or indirectly related to tourism develop because tourism has links with other sectors.

\subsection{Impact of Tourism in Development}

What is meant by the impact of tourism in this study is the influence that arises on the economy of the Province of Bali due to the development of the tourism sector. In this study, the impact of tourism development on the growth of the agricultural sector and labor productivity in the agricultural sector analyzed.

1) Impact of Tourism Development on Agriculture Sector Growth

Between the agricultural sector and the tourism sector a symmetrical-mutualistic relationship occurs. This means that the development of the tourism sector will encourage the development of the agricultural sector. Bali tourism is a leading sector of economic development. The linkage between tourism and agriculture can be seen in various aspects, including the supply-demand of agricultural products, job creation, and so on. The agricultural sector as a supplier of agricultural products such as fruits, vegetables, labor for hotels and restaurants. As cultural tourism, the island of Bali has valuable cultures which are social capital in tourism development.

Having seen a symmetrical-mutualistic relationship between the tourism sector and the agricultural sector, to increase the growth of the agricultural sector in Bali Province, efforts are needed to maintain and even develop tourism in Bali. The central/regional/private government needs to formulate a promotion policy that can increase tourist visits to the Province of Bali and Indonesia. The analysis of the impact of tourism development on the growth of the agricultural sector is carried out with the Regression Panel Data. The results of the analysis are presented in Table 3.

Table 3

Panel data regression analysis results of the impact of tourism development on the agricultural sector growth in Bali Province

\begin{tabular}{|c|c|c|c|c|}
\hline Variable & Coefficient & Std. Error & t-Statistic & Prob. \\
\hline $\mathrm{C}$ & 5.135261 & 0.304739 & 16.85136 & 0.0000 \\
\hline $\mathrm{X}$ ? & 0.596485 & 0.022987 & 25.94888 & 0.0000 \\
\hline \multicolumn{5}{|l|}{ Fixed Effects (Cross) } \\
\hline$\_1-C$ & 0.084501 & Jembrana & & \\
\hline$\_2-\mathrm{C}$ & 0.690768 & Tabanan & & \\
\hline $3-\mathrm{C}$ & -0.919178 & Badung & & \\
\hline$-4-\mathrm{C}$ & -0.162189 & Gianyar & & \\
\hline$-5-C$ & 0.256077 & Klungkung & & \\
\hline$-6-C$ & 0.142956 & Bangli & & \\
\hline _7-C & 0.573391 & Karangasem & & \\
\hline _8-C & -0.288511 & Buleleng & & \\
\hline$-9-\mathrm{C}$ & 0.954835 & Denpasar & & \\
\hline \multicolumn{5}{|c|}{ Effects Specification } \\
\hline \multicolumn{5}{|c|}{ Cross-section fixed (dummy variables) } \\
\hline R-squared & 0.972569 & \multicolumn{2}{|c|}{ Mean dependent var } & 13.04171 \\
\hline Adjusted R-squared & 0.970441 & \multicolumn{2}{|c|}{ S.D. dependent var } & 0.343354 \\
\hline S.E. of regression & 0.059032 & \multicolumn{2}{|c|}{ Akaike info criterion } & -2.745439 \\
\hline Sum squared resid & 0.404233 & \multicolumn{2}{|c|}{ Schwarz criterion } & -2.520337 \\
\hline Log-likelihood & 182.9627 & \multicolumn{2}{|c|}{ Hannan-Quinn criteria } & -2.653987 \\
\hline F-statistic & 456.9810 & \multicolumn{2}{|c|}{ Durbin-Watson stat } & 2.053214 \\
\hline
\end{tabular}




\begin{tabular}{ll}
\hline Prob(F-statistic) & 0.000000 \\
\hline & Source: Analysis of secondary data
\end{tabular}

From the Panel Data Regression results above it can be seen that the coefficient of the variable of tourism development is significant or smaller compared to $\alpha(0.00<0.05)$. Also, the value of R2 produced is very high or $97.04 \%$. This means that variations in the development of the tourism sector can explain $97.04 \%$ of agricultural growth. Modeling with Fix Effects also shows that the impact of change is not the same between one region and another. There are three regencies/cities whose negative intercepts are Badung, Gianyar, and Buleleng. The negative coefficient in the regression intercept shows that when there is no growth in the tourism sector, the growth of the agricultural sector tends to decrease. From the results of the analysis, the impact of tourism development on the growth of the agricultural sector in development in the Province of Bali can be formulated in the form of an equation as follows:

$$
\operatorname{Ln} Y=a+\beta \ln X \text { or } \ln Y=5,13+0,59 \ln x
$$

Where $\mathrm{Y}$ is the agricultural sector and $\mathrm{X}$ is the tourism sector.

Classical assumption testing on the selected model as follows:

a) Heteroscedasticity test can be done using GLS weight. If no significant differences are found with the unweighted one, it is assumed that there is no heteroscedasticity. The test results show that in general there is no significant difference between the results with weight or no weight in the fixeffect model. These results indicate that the model does not experience problems with heteroscedasticity. Test results with GLS weight are presented in Table 4 as follows:

b) Multicollinearity test. This test can be done by calculating the VIF value based on the standard error generated by the model. In this model the resulting VIF value is equal to $\left(\frac{1}{1-e^{2}}\right)=$ $\left(\frac{1}{1-(0.0509)^{2}}\right)=1.0026$. The VIF value produced is far below 10 or it is assumed that there is no multicollinearity in the model.

c) Autocorrelation test. The Durbin-Watson statistical value is not in the critical region or around the value of 2 . This shows that there is no autocorrelation in the model.

Table 4

The results of the classic assumption test of the selected model

\begin{tabular}{crccc}
\hline Variable & Coefficient & Std. Error & t-Statistic & Prob. \\
\hline C & 5.625104 & 0.236173 & 23.81771 & 0.0000 \\
X? & 0.559530 & 0.017815 & 31.40774 & 0.0000 \\
Fixed Effects (Cross) & & & & \\
-1-C & 0.069055 & Jembrana & & \\
-2-C & 0.681158 & Tabanan & & \\
-3-C & -0.869540 & Badung & & \\
-4-C & -0.146533 & Gianyar & & \\
-5-C & 0.224645 & Klungkung & & \\
-6-C & 0.112383 & Bangli & & \\
-7-C & 0.542603 & Karangasem & & \\
-8-C & -0.300724 & Buleleng & & \\
-9-C & 0.914495 & Denpasar & & \\
\hline
\end{tabular}

Effects Specification

Artini, N. W. P., Antara, M., Susrusa, I. K. B., \& Ambarawati, I. (2020). Impact of tourism on development in Bali Province. International Journal of Life Sciences, 4(2), 19-31. https://doi.org/10.29332/ijls.v4n2.429 


\begin{tabular}{|c|c|c|c|}
\hline \multicolumn{4}{|c|}{ Cross-section fixed (dummy variables) } \\
\hline \multicolumn{4}{|c|}{ Weighted Statistics } \\
\hline$\overline{\text { R-squared }}$ & 0.978873 & Mean dependent var & 15.72649 \\
\hline Adjusted R-squared & 0.977233 & S.D. dependent var & 6.350383 \\
\hline S.E. of regression & 0.057967 & Sum squared resid & 0.389774 \\
\hline F-statistic & 597.1684 & Durbin-Watson stat & 0.304753 \\
\hline Prob(F-statistic) & 0.000000 & & \\
\hline \multicolumn{4}{|c|}{ Unweighted Statistics } \\
\hline$\overline{\text { R-squared }}$ & 0.971958 & Mean dependent var & 13.04171 \\
\hline Sum squared resid & 0.413239 & Durbin-Watson stat & 2.041859 \\
\hline
\end{tabular}

Source: Secondary data analyst

Panel Data Regression estimation model with the fixed effect as follows:

a) Coefficient of determination. The value (Adjusted $\mathrm{R}^{2}$ ) obtained in this model is 0.97 or it can be interpreted that the development of tourism in Bali can explain agricultural growth up to $97.04 \%$. Only less than three\% is explained by other factors outside the model.

b) The resulting coefficient $\beta$ reached 0.59 . This can be interpreted that the tourism sector growth of $1 \%$ will be able to drive the growth of the agricultural sector by $0.59 \%$. The positive coefficient also shows that the development of the two sectors is relatively in line. The coefficient value is also significant as seen from the probability value which is lower than $\alpha(0.00<0.05)$

c) Intercept coefficients vary, only it can be seen that there are three districts/cities with negative intercepts, namely Badung, Gianyar, and Buleleng. The negative coefficient in the regression intercept shows that when there is no growth in the tourism sector, the growth of the agricultural sector tends to decrease.

d) F-Statistics value greater than F-table shows that simultaneous tourism development affects agricultural growth.

In general, it can be explained that in the Province of Bali it cannot be denied that tourism is a leading sector in the economy. This sector can attract other sectors to develop. From the results of the regression analysis, it can be seen that if tourism grows by one percent, then this sector can drive the growth of the agricultural sector by $0.59 \%$. Impressive evidence shows that tourism developed in Bali is cultural tourism and that Balinese cultural pillars are in agriculture. For tourism areas such as Badung, Gianyar, and Buleleng the development of the agricultural sector is strongly influenced by the development of tourism. In the three regions, if there is no tourism growth, the growth of the agricultural sector will decline.

2) Impact of tourism development on worker productivity

Tourism has the potential to attract workers in the agricultural sector. This can be seen from the decreasing interest of the younger generation to work in the agricultural sector. The level of wages in the tourism sector is higher than the level of wages in the agricultural sector. With the shift in the workforce from the agricultural sector to the tourism sector, this analysis aims to look at the impact of tourism development on labor productivity in the agricultural sector. The results of an analysis of the impact of tourism development on the growth of the agricultural sector are carried out with the Panel Data Regression. presented in Table 5.

Table 5

The results of the panel data regression analyst of tourism development with labor productivity in Bali Province

\begin{tabular}{ccccc}
\hline Variable & Coefficient & Std. Error & t-Statistic & Prob. \\
\hline $\mathrm{C}$ & -16.63691 & 2.424285 & -6.862605 & 0.0000 \\
\hline
\end{tabular}




\begin{tabular}{|c|c|c|c|c|}
\hline $\mathrm{X}$ ? & 1.407361 & 0.180246 & 7.808010 & 0.0000 \\
\hline \multicolumn{5}{|c|}{ Fixed Effects (Cross) } \\
\hline$-1-\mathrm{C}$ & 0.452172 & Jembrana & & \\
\hline$-2-\mathrm{C}$ & 0.205583 & Tabanan & & \\
\hline _3-C & -1.831147 & Badung & & \\
\hline$-4-C$ & -0.501170 & Gianyar & & \\
\hline -5-C & 1.233141 & Klungkung & & \\
\hline$-6-C$ & 0.629051 & Bangli & & \\
\hline -7-C & 0.453447 & Karangasem & & \\
\hline -8-C & -1.018565 & Buleleng & & \\
\hline$-9-C$ & 0.377489 & Denpasar & & \\
\hline \multicolumn{5}{|c|}{ Effects Specification } \\
\hline \multicolumn{5}{|c|}{$\underline{\text { Cross-section fixed (dummy variables) }}$} \\
\hline R-squared & 0.950248 & \multicolumn{2}{|l|}{ Mean dependent var } & 2.290928 \\
\hline Adjusted R-squared & 0.941800 & \multicolumn{2}{|l|}{ S.D. dependent var } & 0.821528 \\
\hline S.E. of regression & 0.198191 & \multicolumn{2}{|l|}{ Akaike info criterion } & -0.254555 \\
\hline Sum squared resid & 2.081820 & \multicolumn{2}{|l|}{ Schwarz criterion } & 0.085625 \\
\hline Log likelihood & 18.01848 & \multicolumn{2}{|l|}{ Hannan-Quinn criter. } & -0.120761 \\
\hline F-statistic & 112.4770 & \multirow{2}{*}{\multicolumn{2}{|c|}{ Durbin-Watson stat }} & 2.464774 \\
\hline Prob(F-statistic) & 0.000000 & & & \\
\hline
\end{tabular}

Source: Analysis of secondary data

From the analysis results, it can be seen that the coefficient of tourism development has a significant effect (significant) because the value is smaller than $\alpha(0.00<0.05)$. Also, the value of R2 produced was very high at $94.18 \%$. This means that tourism development variables can explain labor productivity as much as $94,18 \%$. Modeling with a fixed effect also shows that the impact of change is not the same between one region and another when seen in its intercept values. From the results of the analysis, the impact of tourism development on labor productivity in development in the Province of Bali can be formulated in the form of a regression equation as follows:

$$
\operatorname{Ln} Y=a+\beta \ln x \text { or } \ln Y=-16,63+1,40 \ln x
$$

Information: $Y$ is labor productivity $\mathrm{x}$ is the development of tourism

Classical Assumption Testing on the model:

a) Heteroscedasticity test can be done using GLS weight. If no significant differences are found with the unweighted one, it is assumed that there is no heteroscedasticity. Test results with GLS weight are presented in Table 6. The analysis results show that in general there is no significant

Artini, N. W. P., Antara, M., Susrusa, I. K. B., \& Ambarawati, I. (2020). Impact of tourism on development in Bali Province. International Journal of Life Sciences, 4(2), 19-31. https://doi.org/10.29332/ijls.v4n2.429 
difference between the results with weight or no weight in the model with a fix-effect. These results indicate that the model does not experience problems with heteroscedasticity.

b) Multicollinearity test. This test can be done by calculating the VIF value based on the standard error generated by the model. In this model the resulting VIF value is equal to $\left(\frac{1}{1-e^{2}}\right)=$ $\left(\frac{1}{1-(0.18)^{2}}\right)=1.033$. The VIF value produced is far below 10 or it is assumed that there is no multicollinearity in the model

c) Autocorrelation test. The Durbin-Watson statistical value is not in the critical region or around the value of 2 . This shows that there is no autocorrelation in the model

Table 6

The results of the classic assumption test of the selected model

\begin{tabular}{|c|c|c|c|c|}
\hline Variable & Coefficient & Std. Error & t-Statistic & Prob. \\
\hline $\mathrm{C}$ & -13.91102 & 1.394178 & -9.977934 & 0.0000 \\
\hline $\mathrm{X} ?$ & 1.204680 & 0.103657 & 11.62177 & 0.0000 \\
\hline \multicolumn{5}{|c|}{ Fixed Effects (Cross) } \\
\hline _1--C & 0.369870 & Jembrana & & \\
\hline _2--C & 0.152395 & Tabanan & & \\
\hline _3--C & -1.558101 & Badung & & \\
\hline _4--C & -0.421435 & Gianyar & & \\
\hline _5--C & 1.066657 & Klungkung & & \\
\hline _6--C & 0.447127 & Bangli & & \\
\hline _7--C & 0.276701 & Karangasem & & \\
\hline _8--C & -0.945229 & Buleleng & & \\
\hline _9--C & 0.612015 & Denpasar & & \\
\hline \multicolumn{5}{|c|}{ Effects Specification } \\
\hline \multicolumn{5}{|c|}{ Cross-section fixed (dummy variables) } \\
\hline \multicolumn{5}{|c|}{ Weighted Statistics } \\
\hline R-squared & 0.932288 & Mean dependen & var & 3.119856 \\
\hline Adjusted R-squared & 0.920790 & S.D. dependent & & 1.005520 \\
\hline S.E. of regression & 0.191407 & Sum squared re & & 1.941750 \\
\hline F-statistic & 81.08083 & Durbin-Watson & & 1.548546 \\
\hline Prob(F-statistic) & 0.000000 & & & \\
\hline \multicolumn{5}{|c|}{ Unweighted Statistics } \\
\hline R-squared & 0.949061 & Mean dependen & var & 2.290928 \\
\hline Sum squared resid & 2.131486 & Durbin-Watson & & 1.422231 \\
\hline
\end{tabular}

The estimated model with fix effect

a) The coefficient of determination. The value (Adjusted $\mathrm{R}^{2}$ ) obtained in this model is 0.94 or it can be interpreted that the development of tourism can explain labor productivity of up to $94.18 \%$.

b) The coefficient value of the tourism development variable $(\beta)$ produced reaches 1.41 . This can be interpreted that the tourism sector growth of one $(1 \%)$ will be able to drive the growth of labor productivity in the agricultural sector by $1.41 \%$. The positive coefficient also shows that the development of the two sectors is in line. The coefficient value of tourism development is also significant seen from the value of the probability which is lower than the value of $\alpha(0.00<0.05)$

c) Intercept coefficients vary, only it can be seen that there are three districts/cities with negative intercepts, namely Badung, Gianyar, and Buleleng. The negative coefficient in the regression intercept shows that when there is no growth in the tourism sector, labor productivity in the agricultural sector will decline. 
d) F-Statistics values that are greater than $\mathrm{F}$ tables indicate that simultaneous tourism development affects labor productivity.

From the model that has fulfilled this classic assumption test, it can be concluded that in analysis, the growth of the tourism sector has played a role in increasing the productivity of workers working in the agricultural sector. This increase is undeniable because in recent years the number of worker forces working in agriculture has continued to decline while the GRDP produced has continued to increase. This decrease was partly due to a shift in employment from agriculture to non-agriculture, especially tourism. This shows that the future challenge of the agricultural sector is basically to maintain the working-age population so they want to work as farmers. This means that the agricultural sector needs attention so that the younger generation is interested in working in the agriculture sector.

\section{Conclusion}

From the results of the research and discussion described previously, it can be concluded that:

1) With the development of tourism in Bali, Bali's economic growth is always above the average national economic growth. Sectors directly related to tourism contributed greatly to the GRDP and tended to increase. While the contribution of the agricultural sector tends to decline.

2) In Bali, there is a synergistic-mutualistic relationship between the tourism sector and the agricultural sector. The development of tourism in Bali Province can significantly increase the growth of the agricultural sector. The growth of the tourism sector by one percent was able to increase the growth of the agricultural sector by 0.59 percent.

3) With the development of the tourism sector in Bali, labor productivity in the agricultural sector has increased significantly. The growth of the tourism sector by one percent can increase labor productivity in the agricultural sector by 1.41 percent.

\section{Suggestions}

1) In the long term, there are fears of labor shortages in the agricultural sector which lead to threats to food self-sufficiency. Therefore, efforts should be made to ensure that young people want to work in the agricultural sector.

2) To partner the tourism sector with a permanent agricultural sector, there needs to be government intervention in making regulations.

3) The need for similar research with sharper analysis and more variables to be able to describe the Bali economy as a whole.

\section{Acknowledgments}

Thankfulness to the rector and vice-rector of Udayana University, the dean and assistant of dean, and all lecturers in the Faculty of Agriculture who have supported and guidance writers during the studying process. Acknowledgment also goes to Promotor and Co. Promotor I and II have been providing support and a wide range of assistance, so the paper can be completed properly. All families who have been helped in the material writer say thank you.

Artini, N. W. P., Antara, M., Susrusa, I. K. B., \& Ambarawati, I. (2020). Impact of tourism on development in Bali Province. International Journal of Life Sciences, 4(2), 19-31. https://doi.org/10.29332/ijls.v4n2.429 


\section{References}

Amerta, I. M. S., Sara, I. M., \& Bagiada, K. (2018). Sustainable tourism development. International Research Journal of Management, IT and Social Sciences, 5(2), 248-254.

Belisle, F. J., \& Hoy, D. R. (1980). The perceived impact of tourism by residents a case study in Santa Marta, Colombia. Annals of tourism research, 7(1), 83-101. https://doi.org/10.1016/S0160-7383(80)80008-9

Davenport, J., \& Davenport, J. L. (2006). The impact of tourism and personal leisure transport on coastal environments: a review. Estuarine, coastal and shelf science, 67(1-2), 280-292. https://doi.org/10.1016/j.ecss.2005.11.026

Fletcher, J. E. (1989). Input-output analysis and tourism impact studies. Annals of tourism research, 16(4), 514529. https://doi.org/10.1016/0160-7383(89)90006-6

Harianto (2007). Peranan Pertanian Dalam Ekonomi Pedesaan sebuah makalah seminar yang disampaikan pada Seminar nasional "Dinamika Pembangunan Pertanian dan Pedesaan: Mencari Alternatif Arah Pembangunan Ekonomi Rakyat", Pusat Analisis Sosial Ekonomi dan Kebijakan Pertanian Departemen Pertanian, Bogor.

Johnston, B. F., \& Mellor, J. W. (1961). The role of agriculture in economic development. The American Economic Review, 51(4), 566-593.

Kuznets, S. (1964). Quantitative aspects of the economic growth of nations: IX. Level and structure of foreign trade: Comparisons for recent years. Economic Development and Cultural Change, 13(1, Part 2), 1-106.

Lewis, W. A. (1954). Economic development with unlimited supplies of labour.

Milman, A., \& Pizam, A. (1988). Social impacts of tourism on central Florida. Annals of tourism research, 15(2), 191-204. https://doi.org/10.1016/0160-7383(88)90082-5

Perdue, R. R., Long, P. T., \& Allen, L. (1987). Rural resident tourism perceptions and attitudes. Annals of Tourism Research, 14(3), 420-429. https://doi.org/10.1016/0160-7383(87)90112-5

Pitana, I. G. (1999). Pelangi Pariwisata Bali. Denpasar: Bali Post.

Seetanah, B. (2011). Assessing the dynamic economic impact of tourism for island economies. Annals of tourism research, 38(1), 291-308. https://doi.org/10.1016/j.annals.2010.08.009

Wisudawati, N. N. S., \& Maheswari, A. I. A. (2018). Potential of Silver Craft Product through to CommunityBased for Tourism Sustainability in Celuk Village. International Research Journal of Management, IT and Social Sciences, 5(1), 9-15. 


\section{Biography of Authors}

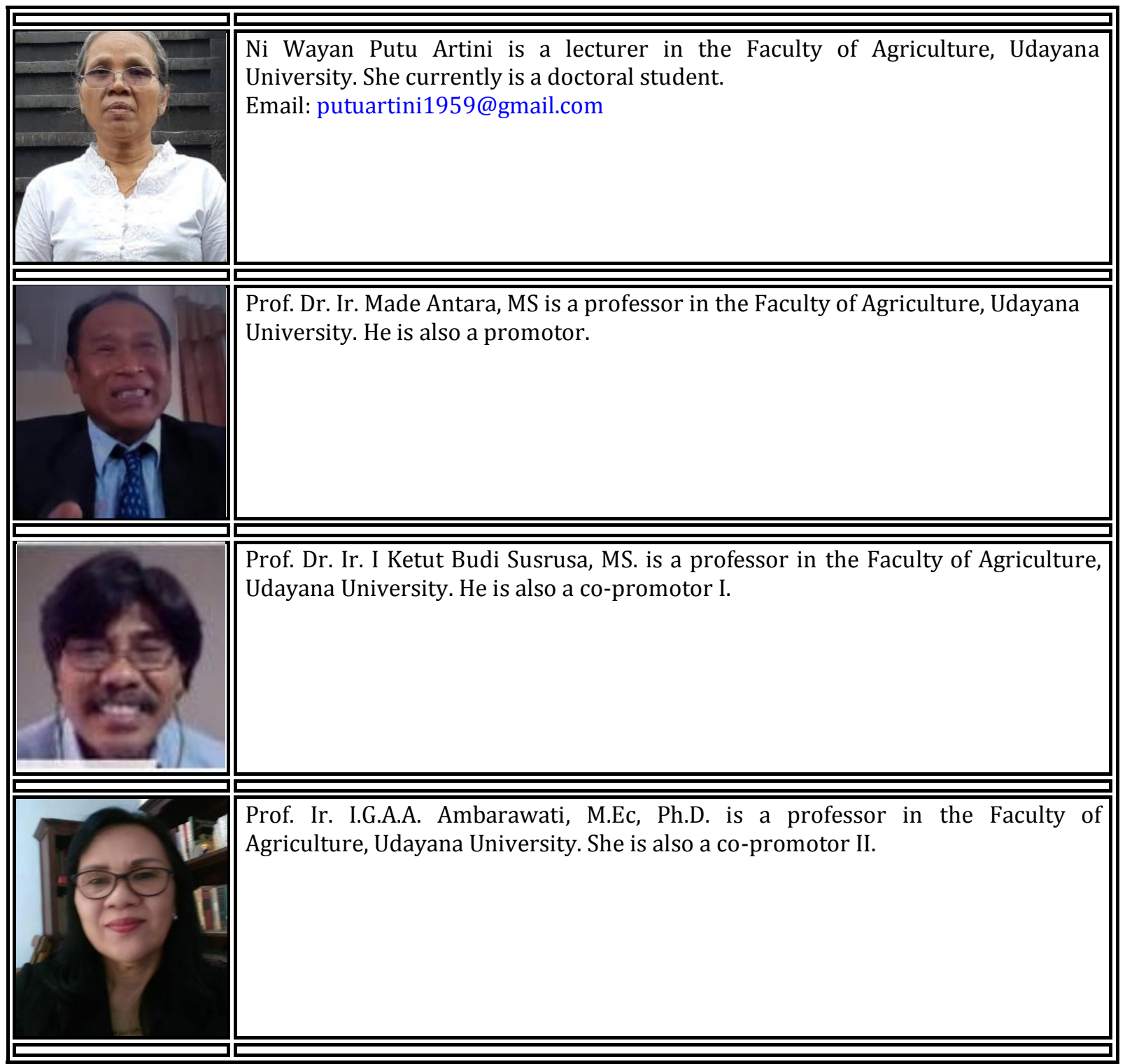

Artini, N. W. P., Antara, M., Susrusa, I. K. B., \& Ambarawati, I. (2020). Impact of tourism on development in Bali Province. International Journal of Life Sciences, 4(2), 19-31. https://doi.org/10.29332/ijls.v4n2.429 